\title{
PENGARUH PENERAPAN METODE CUL-DE-SAC (NOSE PINCHING) TERHADAP KLIEN DISGLOSIA
}

\author{
Riani Shopianty ${ }^{*}$, Tita Suci Rahayu \\ Politeknik Al Islam Bandung \\ Email: ria.shopia@gmail.com
}

\begin{abstract}
ABSTRAK
Gangguan bicara yang terjadi akibat adanya kelainan bentuk dan atau struktur organ bicara, khususnya artikulator, disebut Disglosia. Kelainan bentuk atau organ wicara yang dialami sejak bayi, mengakibatkan penderita mendapatkan berbagai kesulitan dalam berkomunikasi karena adanya ketidaktepatan atau ketidakkonsistenan dalam mengartikulasikan kata. Salah satu metode pada bidang terapi wicara yang dapat digunakan untuk menangani masalah tersebut termasuk kelainan pada resonansi suara adalah Metode Cul-de-sac (Nose Pinching). Penelitian ini bertujuan untuk mengetahui pengaruh penerapan metode Cul-de-sac dalam meningkatkan kesadaran klien Disglosia akan perbedaan resonansi suara di rongga hidung dan rongga mulut pada saat memproduksi konsonan dan mengurangi nasal air emission pada saat memproduksi huruf konsonan sibilant apicoalveolar/s/di Yayasan Pembina Penderita Celah Bibir dan Langit- langit Cleft Center Bandung. Metode penelitian yang digunakan adalah Eksperimen Subjek Tunggal. Pengumpulan data dilakukan melalui wawancara dengan orang tua klien, observasi secara langsung terhadap klien, pemberian tes, dan studi dokumen rekam medis klien. Setelah dilakukan 15 kali pertemuan terapi dengan menggunakan metode di atas, kemampuan klien bertambah sekitar 27,2\% dan berhasil mengucapkan konsonan /s/ dengan adanya nasal air emission antara 1-2 cm. Sehingga, berdasarkan hasil tersebut dapat disimpulkan bahwa metode Cul-de-sac (Nose Pinching) berpengaruh dalam mengurangi nasal air emission pada pasien disglosia di atas.
\end{abstract}

Kata kunci: disglosia, konsonan /s/, metode cul-de-sac

\section{ABSTRACT}

A speech disorder that occurs due to deformities of speech organs, especially articulators, is called dysglosia. The congenital deformities of speech organs of people around us result in various difficulties in communicating due to inaccuracies or inconsistencies in articulating words. One of the methods in the field of speech therapy being able to overcome the problems including the abnormalities in sound resonance is Cul-de-sac (Nose Pinching) method. This study aimed to determine the effect of the application of the Cul-de-sac (Nose Pinching) method in increasing the awareness of Dysglosia clients about the differences in sound resonance in the nasal cavity and oral cavity when producing consonants and reducing nasal air emissions when producing consonant sibilant apicoalveolar / s. / at the Cleft Center Bandung. The research method used is a single-subject experiment. Data were collected through interviews with the client's parents, direct observation of the client, tests, and a document study of the client's medical record. After 15 sessions of therapy using the method, the 
client's ability had improved by about $27,2 \%$ and he was successfully able to pronounce the consonant of / $s /$ in the presence of a nasal air emission between 1-2 $\mathrm{cm}$. Therefore, based on the results it can be concluded that the Cul-de-sac (Nose Pinching) method has influenced nasal air emission reduction.

Keywords: cul-de-sac method, dysglossia, /s/ consonant

\section{PENDAHULUAN}

Komunikasi merupakan aktivitas individu dasar manusia, melalui komunikasi manusia dapat saling berhubungan satu sama lain dan mampu menciptakan sebuah interaksi sosial baik individu dengan individu, individu dengan kelompok, serta kelompok dengan kelompok. Tidak adanya komunikasi dengan baik mengakibatkan ketidakteraturan dalam melaksanakan sebuah kegiatan. Komunikasi salah satunya terkait dengan proses berbicara. Tarigan (2008) menjelaskan bahwa kegiatan berbicara berkaitan dengan kemampuan manusia dalam mengucapkan bunyi-bunyi artikulasi atau kata-kata untuk mengekspresikan, menyatakan serta menyampaikan pikiran, gagasan, dan perasaan. Kegiatan berbicara sendiri merupakan proses psiko-fisik. Ini berarti bahwa dalam berbicara faktor kemampuan manusia dalam mengucapkan bunyi-bunyi artikulasi atau kata-kata sangat tergantung pada kondisi fisik yang berkaitan dengan organ wicara sebagai alat ucap penghasil suara. Sementara faktor-faktor lain yang mendukung keberhasilan kegiatan berbicara yang bersifat non fisik berkaitan dengan psikologis, semantik, dan lingkungan.

Kelainan bentuk atau struktur organ bicara pada manusia dapat menyebabkan terganggunya proses pengeluaran bunyi artikulasi atau kata-kata yang pada bidang terapi wicara dikenal dengan istilah disglosia. Gangguan ini dapat menimbulkan masalah dalam proses komunikasi yang melibatkan 3 komponen pengirim (sender), pesan (message), dan penerima (receiver). Sebagai pengirim, penderita disglosia yang mengalami gangguan dalam mengartikulasikan kata akan gagal menyampaikan ide, gagasan, atau perasaan (message) secara normal. Hal ini bisa mengakibatkan penerima tidak memahami atau mengerti pesan yang disampaikan. Sehingga proses komunikasi tidak berjalan sesuai dengan yang diharapkan.

Menurut Margulis (2002) dalam Zainul (2013), di Asia rasio kemungkinan anak lahir dengan celah bibir dan langit-langit (palatum) adalah 0,45-0,5/1000 kelahiran. Terjadinya celah palatum diakibatkan adanya kegagalan penyatuan dua prosesus maksilaris kiri dan kanan atau kegagalan penyatuan prosesus fronto nasalis pada saat perkembangan janin. Celah palatum dapat dikoreksi dengan pembedahan, yang dikenal dengan istilah palatoplasti. Pembedahan ini bertujuan untuk membentuk kondisi anatomis celah langit-langit yang normal dengan cara membuat celah itu menjadi tertutup. Sehingga veloparingeal penderita akan mejadi lebih baik dan membantu proses kegiatan berbicara yang maksimal.

Bagi penderita celah bibir bawaan, ketika sudah melakukan pembedahan akan membutuhkan waktu untuk beradaptasi mengartikulasikan kata secara benar. Salah satu metode terapi yang digunakan untuk menangani masalah ini adalah metode cul-de-sac (nose pinching).

Penelitian ini dibatasi pada penerapan metode Cul-de-sac terhadap klien Disglosia paska operasi labio palate schizis unilateral jenis kelamin perempuan umur 4 tahun yang ditemukan di Yayasan Penderita Celah Bibir dan Langit-langit Cleft Center. Warren et al. (1988) mengemukakan bahwa salah satu akibat dari kelainan celah bibir dan langit-langit adalah timbulnya nasal air emission yang tidak langsung normal ketika sudah dioperasi. Metode Cul-de-sac (Nose Pinching) dipilih karena sesuai modalitas yang dimiliki serta sesuai dengan kebutuhan klien. Metode Cul-de-sac 
(Nose Pinching) ini akan membantu pasien untuk mengurangi nasal air emission pada konsonan /s/ tingkat suku kata dan kata pada posisi /s-/, /-s-/, /-s/.

Masalah yang dirumuskan dalam penelitian ini adalah sejauh mana pengaruh penerapan metode Cul-de-sac (nose pinching) terhadap klien di atas. Sehingga penelitian ini selain bertujuan untuk mengetahui dan mendeskripsikan pengaruh penerapan metode tersebut terhadap pasien disglosia juga untuk menambah pengetahuan dan referensi pada pembelajaran mata kuliah disglosia di Politeknik Al Islam Bandung.

\section{METODOLOGI PENELITIAN}

Penelitian ini termasuk ke dalam jenis penelitian kuantitatif dengan metode eksperimen subjek tunggal (Single Subject Research (SSR)). Sugiyono (2011) mengatakan bahwa metode penelitian eksperimen diartikan sebagai metode penelitian yang digunakan untuk mencari pengaruh perlakuan tertentu terhadap yang lain dalam kondisi yang terkendalikan. Menurut Sunanto dkk (2005), Single Subject Research (SSR) atau penelitian subjek tunggal, yakni suatu metode penelitian eksperimen yang dilaksanakan pada subjek tunggal dengan tujuan untuk mengetahui besarnya pengaruh dari perlakuan yang diberikan secara berulang-ulang terhadap perilaku yang ingin dirubah dalam waktu tertentu. Metode ini dipilih karena disesuaikan dengan kebutuhan peneliti untuk menilai pengaruh suatu tindakan terhadap tingkah laku atau meguji ada tidaknya pengaruh tindakan itu. Penelitian ini menggunakan Single Subject Research (SSR) dengan menggunakan desain $\mathrm{A}_{1}-\mathrm{B}-\mathrm{A}_{2}$ di mana $\mathrm{A}_{1}$ adalah kondisi baseline, $\mathrm{B}$ adalah kondisi intervensi, serta $\mathrm{A}_{2}$ adalah fase intervensi.

Instrumen penelitian adalah alat bantu yang dipilih dan digunakan oleh peneliti dalam kegiatannya mengumpulkan data agar kegiatan tersebut menjadi sistematis dan mudah (Sugiantoro, 2013). Instrumen ini digunakan untuk mengukur kemampuan awal pasien sebelum mendapatkan terapi dan kemampuan akhir setelah dilakukan terapi.

Tabel 1. Teknik, Responden, dan Indikator Penelitian

\begin{tabular}{|c|c|c|c|}
\hline No & $\begin{array}{c}\text { Teknik Pengumpulan } \\
\text { Data }\end{array}$ & Responden & Indikator \\
\hline 1. & Wawancara & Orang Tua Klien & $\begin{array}{l}\text { BiodatData penyebab, Riwayatperkembangan } \\
\text { bahasa, bicara, motorik, sosial, perilaku dan } \\
\text { Riwayat kesehatan keluarga. }\end{array}$ \\
\hline 2. & Observasi & Klien & $\begin{array}{l}\text { Pengamatan kondisi fisik, kemampuan } \\
\text { motorik, sensorik, bahasa, bicara, suara, irama } \\
\text { kelancaran, pernafasan, perilaku, sosial dan } \\
\text { emosi. }\end{array}$ \\
\hline 3. & Pemeriksaan Organ Wicara & Klien & $\begin{array}{l}\text { Pemeriksaan struktur dan fungsi organ wicara } \\
\text { yang meliputi, bibir, gigi, lidah, langit-langit, } \\
\text { palatopharynx, nasal cavities dan pergerakan } \\
\text { oral yang disengaja. }\end{array}$ \\
\hline 4. & $\begin{array}{l}\text { Pemeriksaan Kemampuan } \\
\text { Wicara }\end{array}$ & Klien & $\begin{array}{l}\text { Pemeriksaan kemampuan wicara klien dalam } \\
\text { memproduksi suku kata. }\end{array}$ \\
\hline 5. & Tes Artikulasi & Klien & $\begin{array}{l}\text { Pemeriksaan kemampuan berartikulasi tingkat } \\
\text { kata }\end{array}$ \\
\hline 5. & Tes Bahasa & Klien & $\begin{array}{l}\text { Pemeriksaan kemampuan pemahaman bahasa } \\
\text { lisan dan kemampuan lisan klien mulai dari } \\
\text { usia } 7 \text { tahun sampai usia kalendernya. }\end{array}$ \\
\hline & $\begin{array}{l}\text { Deteksi Dini Gangguan } \\
\text { Kemampuan Berkomunikasi }\end{array}$ & & $\begin{array}{l}\text { Pemeriksaan kemampuan pemahaman bahasa } \\
\text { lisan dan kemampuan lisan klien mulai dari } \\
\text { usia } 6 \text { bulan sampai } 7 \text { tahun. }\end{array}$ \\
\hline 7. & Pemeriksaan Bahasa Secara & Klien & Pemeriksaan pemahaman bahasa mengenai \\
\hline
\end{tabular}




\begin{tabular}{|c|c|c|c|}
\hline & Auditori & & kata benda, kata sifat, bilangan, kata penunjuk, \\
\hline 8. & Tes Suara & Klien & $\begin{array}{l}\text { Pemeriksaan suara klien dari segi nada, } \\
\text { kualitas dan kenyaringan. }\end{array}$ \\
\hline 9. & Tes Irama Kelancaran & Klien & $\begin{array}{l}\text { Pemeriksaan irama klien apakah terjadi } \\
\text { pengulangan, perpanjangan atau penghentian. }\end{array}$ \\
\hline 10. & Anamnesa Makan Minum & Orang Tua Klien & $\begin{array}{l}\text { Dilakukan untuk mengetahui kemampuan } \\
\text { menelan klien berkaitan denganjenis makanan } \\
\text { yang dimakan, cara makan klien, frekuensi dan } \\
\text { lama makan, serta ada tidaknya masalah } \\
\text { menelan. }\end{array}$ \\
\hline 11 & Tes Dexter Quotient & Klien & Untuk mengetahui dominan ketanganan \\
\hline 12 & Tes Awal dan tes akhir & Klien & $\begin{array}{l}\text { Untuk mengetahui perbandingan keberhasilan } \\
\text { terapi }\end{array}$ \\
\hline 13 & Alat penunjang terapi & Klien & $\begin{array}{l}\text { Noise clip, stethoscope, straw, listening tube, } \\
\text { mirror test, alat perekam audio, alat tiup, kartu } \\
\text { huruf }\end{array}$ \\
\hline
\end{tabular}

\section{Hasil Pelaksanaan Terapi}

Metode Cul-de-sac (Nose Pinching) menitikberatkan pada pendengaran sebelum memproduksi bunyi. Setelah bunyi dapat diproduksi secara tunggal, selanjutnya diproduksi dengan bermacammacam tingkatan dengan menggunakan stimulasi pendengaran.

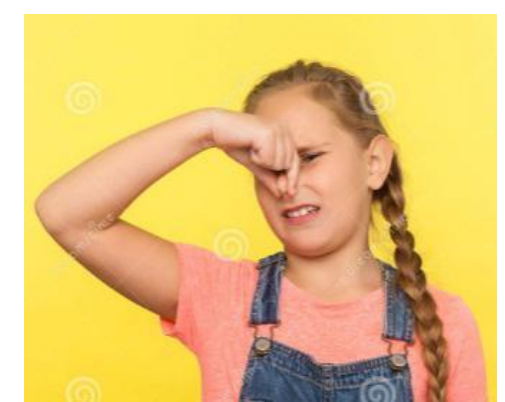

Gambar 1. Metode Cul-de-sac (Nose Pinching)

Materi yang dipilih konsonan /s/ pada tingkat suku kata, dan kata. Mengucapkan /s/, mengucapkan suku kata /sa/, /si/, /su/, /se/, /so/, mengucapkan kata /sepatu/, /sekolah/, /sapi/, /pensil/, /kismis/, /susu/, /tas/, /bus/, /tikus/.

Berikut ini adalah langkah-langkah metode Cul-de-sac (Nose Pinching), diantaranya sebagai berikut:

a. Meminta klien untuk memproduksi konsonan sibilant apicoalveolar $/ \mathrm{s} /$ dengan mendesiskan dihitung sebanyak $3 x$ pengulangan

b. Meminta klien untuk memproduksi konsonan sibilant apicoalveolar/s/tingkat suku kata pada /sa/, /si/, /su/, /se/, /so/ dihitung sebanyak 5x hitungan dengan 3x pengulangan

c. Meminta klien untuk memproduksikan konsonan sibilant apicoalveolar/s/ pada tingkat kata pada posisi /s-/ yaitu /sepatu/, /sekolah/, /sapi/, /-s-/ yaitu /pensil/, /kismis/, /susu/, /-s/ yaitu /tas, bus/, /tikus/, dihitung sebanyak 1x hitungan dengan 3x pengulangan. 
d. Langkah tersebut dilakukan dengan penutupan lubang hidung oleh jarinya sendiri atau terapis maupun dengan alat terapi yaitu nose clip atau stetoscope terlebih dahulu, kemudian pengulangan produksi konsonan sibilant apicoalveolar/s/ dengan lubang hidung terbuka.

\section{HASIL DAN PEMBAHASAN}

\section{Hasil Wawancara}

Berdasarkan hasil wawancara diperoleh keterangan bahwa ibu klien saat hamil umur 30 tahun, ibu mengikuti program kehamilan dan pemeriksaan pertama dilakukan usia 6 minggu. Saat trimester pertama usia kandungan 2 sampai 3 bulan ibu rutin pergi ke Sumedang, sehingga ibu klien sering merasa mual dan kecapean. Kondisi ini berpengaruh terhadap asupan nutrisinya, sehingga pada saat kehamilan ibu hanya bertambah $1 \mathrm{~kg}$ per bulannya. Padahal penambahan berat badan dan asupan nutrisi selama kehamilan berpengaruh pada pembentukan organ tubuh janin (Muhammad et al., 2014). Selama kehamilan ibu klien tidak melakukan USG (Ultrasonografi) dan hanya melakukan pemeriksaan ke bidan selama kehamilan. Ibu melahirkan ditangani oleh bidan pada usia kehamilan 9 bulan dengan proses lahir spontan. Klien lahir dengan berat badan 3000gram dan langsung menangis saat dilahirkan. Setelah melahirkan ibu menyadari bahwa klien memiliki celah bibir dan langit- langit. Setelah empat jam dari kelahiran, klien dirujuk ke Rumah Sakit Hasan Sadikin Bandung untuk program menyusui selama satu minggu. Pada saat klien berusia 19 bulan klien dirujuk ke Cleft Center Bandung melakukan operasi langit-langit. Setelah itu klien mampu memproduksi vokal, konsonan, suku kata, kata, frase dan kalimat. Namun pada saat memproduksi konsonan sibilant apicoalveolar /s/ terdapat adanya nasal air emission yaitu keluarnya udara yang berlebih dari hidung.

Riwayat kemampuan perkembangan bahasa bicara klien sesuai dengan perkembangannya dan tidak pernah kesulitan dalam mengungkapkan keinginannnya, terbukti jika dipanggil namanya klien menoleh dan saat diperintahkan klien mengerti dan dapat melakukannya.

\section{Hasil Observasi}

Berdasarkan hasil observasi secara fisik klien mengalami celah bibir dan langit- langit. Walaupun demikian secara umum kondisi fisik klien normal dengan ciri rambut lurus, tipis, pendek, warna rambut hitam agak pirang, bibir lembab, warna kulit kuning langsat tidak pucat, tidak menggunakan alat bantu dengar, dan tidak memakai kacamata, kursi roda maupun tongkat.

\section{Hasil Tes}

\section{Tes Pemeriksaan Alat Wicara}

Berdasarkan Hasil Pemeriksaan Alat Wicara diperoleh data bahwa alat wicara klien mengalami deviasi sedang dan memungkinan mempengaruhi wicara sehingga perlu pelayanan perbaikan. Hasil tes pergerakan oral yang disengaja mendapat nilai 3 yang berarti tugas atau perintah yang diberikan dapat dilaksanakan dengan tepat setelah mencoba dan mencari, akan tetapi gerakan dapat dilaksanakan dengan diberi contoh terlebih dahulu oleh pengujinya.

\section{Tes Pemeriksaan Kemampuan Wicara}

Klien mampu meniru vokal, konsonan, suku kata dan kata yang diucapkan penguji namun ada pengucapan yang belum konsisten pada konsonan dengan seluruh vokal /ng/, /r/, /s/. Selain itu pada hasil Tes Artikulasi terjadi substitusi pada /f-, -f-, -f, v-, -v-, z-, -z-, -z, -r, br-, fr, gr-, pr-/ dan terjadi omisi pada konsonan /-g, -s-. -s-, sk-/. 
3. Tes suara

Nada suara klien cenderung rendah, kualitas suara klien terdengar sengau hipernasal dan nyaring.

\section{Hasil Analisis}

Data yang telah diperoleh dari hasil wawancara, observasi dan juga tes, kemudian dianalisis. Dari hasil wawancara didapat kesimpulan bahwa ibu klien mengalami malnutrisi yang dipengaruhi oleh kurangnya asupan makanan bergizi akibat adanya gejala mual dan kelelahan. Menurut Arisman (2009) bahwa kekurangan nutrisi ini dapat mengganggu proses perkembangan janin di dalam rahim, dan diperkuat oleh Yani (2013) bahwa nutrisi gizi yang baik ketika kehamilan berlangsung sangat membantu ibu hamil dan janin dalam menjalani hari-hari kehamilannya. Selama kehamilan, kebutuhan nutrisi ibu akan meningkat, seperti kebutuhan kalsium, zat besi, serta asam folat, dan makanan yang baik dan bergizi. Kurangnya asupan makanan juga mengakibatkan penambahan berat badan ibu hamil yang kurang (hanya $1 \mathrm{~kg}$ perbulan). Menurut Blott (2009) kenaikan berat badan ideal ibu hamil tidak lebih dari 2,2 kg pada trimester pertama, 5,5-9 $\mathrm{kg}$ pada trimester kedua, dan 3,5-5 kg pada trimester ketiga. Di sisi lain, pembentukan langit- langit pada janin terjadi pada minggu ke 9-12 minggu. Palatum (langit-langit) tumbuh horizontal dari kedua prosesus maksilaris saling mendekati dan akan terletak di belakang yang disebut palatum - primer. Peleburan kedua palatum terjadi mulai minggu ke 8 sampai dengan ke 12. Mula- mula kontak dibuat dengan palatum primer dan kemudian bertumbuh terjadi ke arah depan maupun belakang. Pada kehamilan minggu ke 13, fusi (peleburan) ini telah lengkap. Apabila dalam periode ini timbul suatu faktor etiologi atau penyebab yang menghambat pertumbuhan, maka yang terbentuk biasanya hanya ada celah di langit- langit lunak (palatum molle).

Hasil tes kemampuan wicara menunjukkan bahwa klien mampu memproduksi vokal, konsonan, suku kata, kata, frase, dan kalimat. Namun pada saat memproduksi konsonan sibilant apicoalveolar /s/ terdapat adanya nasal air emission yaitu keluarnya udara yang berlebih dari hidung. Menurut Kevin Stuckey (2006), "Nasal emission occurs because of velopharyngealdysfunction or incompetence such as a cleft palate, a deep pharynx, paralysis, ora motor - speech disorder. Nasal emission can be present when too much air escapes during production of consonants that require abuil up of air (plosives, fricatives, affricates: Speech can sound distorted since extra air escapes". Artinya Nasal emisi terjadi karena disfungsi velopharing atau ketidakmampuan seperti celah langit - langit mulut, faring, kelumpuhan atau gangguan gerak motor yang dalam. Nasal emisi terjadi saat terlalu banyak udara yang keluar selama produksi konsoanan yang membutuhkan penumpukkan udara (plosive, frikatif, afrikatif), ujaran yang dihasilkan dapat menjadi tidak jelas karena adanya udara yang keluar. Selain itu, klien juga mengalami substitusi pada /f-, -f-, -f, v-, -v-, z-, -z-, -z, -r, br-, fr, gr-, pr-/ dan terjadi omisi pada konsonan /-g, -s-. -s-, sk-/. Sementara itu Templin (1978) menjelaskan bahwa perkembangan artikulasi usia 3 tahun adalah pada konsonan awal /m/, /n/, /p/, /t/, /k/, /b/, /d/, /g/, /f/, /h/, /w/, konsonan posisi tengah /m/, /n/, /p/, /k/, / b/, /d/, /g/, /f/, /h/, /w/, /ng/ konsonan posisi akhir /m/, /n/, /p/, /t/, /ng/. Pada usia 3,5 tahun konsonan awal /y/, posisi tengah /s/, /z/, /y/ konsonan posisi akhir /r/. Peneliti menyimpulkan bahwa klien mengalami gangguan artikulasi berupa substitusi pada konsonan labiodental; /f-/, /-f-/, / -f/, sibilant apicoalveolar /-z-/, roll apicoalveolar /-r/, konsonan kluser/br-/, /fr/, /gr/, /pr/, omisi pada konsonan sibilant apikoalveolar/-s-/, konsonan kluser/sk-/ distorsi pada konsonan dorsovelar /-k/.

Berkenaan dengan sindroma suara yang diperiksa ketika klien diminta untuk menceritakan gambar tentang liburan, klien mengucapkan vocal /a/, /i/, /u/, /e/, /o/, konsonan /p/, /b/, /m/, dan angka 1-10 dengan kualitas suara klien yang terdengar sengau. Menurut Manohar dan Jayaran (1983) bahwa "From 1.454 school children in Mysore City, 97 of the chidren of 5 to 14 years old had voice problems, including quality, pitch, and intensity deviations". Dijelaskan bahwa dalam sebuah survei dari 1.454 anak sekolah di Mysore ditemukan 97 anak anak berusia 5 sampai 14 tahun 
memilik masalah suara, yang termasuk didalamnya berkenaan kualitas, nada dan penyimpangan intensitas.

Menurut Suripto (2005), bahwa celah kedua kiri dan kanan disebut cleft palate bilateral, sedangkan hanya sebelah saja disebut cleft palate unilateral. Gangguan bicara ini ditandai dengan timbulnya suara sengau dan tidak jelas sehingga tidak dapat dimengerti oleh orang lain. Hal ini karena terjadi kesalahan artikulasi dan adanya usaha untuk mengganti pola bicara. Berdasarkan analisa data diatas maka diagnosa klien adalah Disglosia karena mengalami celah bibir dan langit-langit dengan sindroma sebagai berikut:

1. Masih terdapat fistula pada langit- langit keras

2. Gangguan pergerakan oral motor; klien tidak mampu menjulurkan lidah ke arah hidung, menyentuh lidah ke apicoalveolar sambil berbunyi atau mendecak, menjulurkan lidah kearah dagu, dan batuk.

3. Adanya gangguan artikulasi yaitu;

a. Substitusi pada konsonan; labiodental /f-/, /-f-/, /-f/, sibilant apicoalveolar /-z-/, roll apicoalveolar /-r/, konsonan kluser /br-/, /fr/, /gr-/, /pr-/.

b. Omisi tingkat kata pada konsonan sibilant apicoalvolar/-s-/ konsonan kluser /sk-

4. Suara klien terdengar sengau atau hipernasal, dan terdapat nasal air emission pada konsonan sibilant apicoalveolar $/ \mathrm{s} /$.

Metode Cul-de-sac (Nose Pinching) dilakukan sesuai modalitas yang dimiliki serta kebutuhan klien. Peneliti mengambil metode Cul-de-sac (Nose Pinching) untuk mengurangi nasal air emission pada konsonan /s/ tingkat suku kata, dan kata pada posisi /s-/, /-s-/, /-s/. Setelah klienn mampu membedakan produksi nasal, peneliti mampu mengukur tingkat keberhasilan penggunaan metode Cul- de-Sac (Nose Pintching) tersebut.

Penyebab dilakukannya Cul-de-sac dapat bervariasi tetapi biasanya karena adanya penyumbatan di suatu tempat di saluran vokal. Sebagai contoh dapat terjadi pad individu yang mengalami pembesaran tonsile yang menghalangi pintu masuk ke rongga mulut. Energi suara yang terperangkap dan getaran terjadi terutama pada orofaring. Penyebab lain Cul-de-sac resonansi adalah kombinasi di disfungsi velopharingeal dan penyumbatan anterior rongga hidung, penyumbatan ini bisa disebabkan oleh septum yang menyimpang, polip hidung, atau penyempitan hidung. Didalam situasi ini, energi suara bergema di rongga hidung, tetapi tidak dilepaskan melalui lubang hidung (Kummer, 1993., Shprintzen,1987).

Karena resonansi Cul-de-sac adalah kelainan struktural terutama penyumbatan salah satu rongga yang beresonansi, jenis gangguan resonansi memerlukan intervensi medis atau bedah untuk menghilangkan penyebab resonansi. Beberapa individu yang menunjukkan hyponasality dan nasal air emissi (yang memiliki penyebab yang sama seperti hypernasality) memiliki skor nasal yang tinggai pada nasometer karena tingkat emisi udara yang sangat nasal. Penyebab umum dari kondisi ini adalah karena jaringan adenoid tidak beraturan. Sebelum memproduksi suara lisan, velum menutup adenoid, tetapi penyempitan velopharingeal tidak dapat diperoleh karena sumbing atau 'divot' pada jaringan adenoid. Maka hasilnya, terdapat udara yang keluar dari hidung. Disamping itu, ketika velum bergerak untuk produksi suara nasal, adenoid cukup besar sehingga menghambat transmisi suara ke dalam rongga hidung, sehingga menyebabkan hyponasality (Warren \& Dalston,1991).

Latihan dengan mengunakan metode ini dilakukan dengan pelaksanaan terapi 35 menit, frekuensi 2-3 kali perminggu, dilakukan sebanyak 15 kali pertemuan dan 1 kali evaluasi yang telah dilakukan sesuai dengan pelaksanaan terapi 
Terlebih dahulu peneliti melakukan tes awal untuk menilai seberapa banyak nasal air emission pada saat klien memproduksi konsonan /s/ tingkat suku kata dan kata posisi /s-/, /-s-/, /-s/ dinilai menggunakan mirror test. Adapun perbandingan antara hasil tes awal dan tes akhior yang dilakukan kepada klien ditunjukkan oleh Tabel 2.

Tabel 2. Perbandingan Hasil Tes Awal dan Akhir

\begin{tabular}{|c|c|c|c|c|c|c|c|c|c|}
\hline \multirow[t]{2}{*}{ No } & \multirow[t]{2}{*}{ Tes Item } & \multicolumn{4}{|c|}{ Penilaian Tes Awal } & \multicolumn{4}{|c|}{ Penilaian Tes Akhir } \\
\hline & & $\mathbf{M}$ & $\mathbf{C M}$ & $\mathbf{K M}$ & BM & $\mathbf{M}$ & $\mathbf{C M}$ & $\mathbf{K M}$ & BM \\
\hline 1 & $\begin{array}{l}\text { Mengucapkan konsonan sibilant } \\
\text { apicoalveolar /s/ }\end{array}$ & & & 1 & & & 2 & & \\
\hline 2 & $\begin{array}{l}\text { Mengucapkan suku kata /sa/, } \\
\text { /si/, /su/, /se/, /so/ }\end{array}$ & & & 1 & & & 2 & & \\
\hline 3 & $\begin{array}{l}\text { Mengucapkan kata pada /s-/ } \\
\text { 'sepatu' }\end{array}$ & & & 1 & & & & 1 & \\
\hline 4 & $\begin{array}{l}\text { Mengucapkan kata pada /s-/ } \\
\text { 'sekolah' }\end{array}$ & & & 1 & & & & 1 & \\
\hline 5 & $\begin{array}{l}\text { Mengucapkan kata pada /s-/ ' } \\
\text { sapi }\end{array}$ & & & 1 & & & 2 & & \\
\hline 6 & $\begin{array}{l}\text { Mengucapkan kata pada /-s-/ } \\
\text { 'pensil' }\end{array}$ & & & 1 & & & 2 & & \\
\hline 7 & $\begin{array}{l}\text { Mengucapkan kata pada /- s-/ } \\
\text { 'kismis' }\end{array}$ & & & 1 & & & 2 & & \\
\hline 8 & $\begin{array}{l}\text { Mengucapkan kata pada /-s-/ ' } \\
\text { susu' }\end{array}$ & & & 1 & & & 2 & & \\
\hline 9 & $\begin{array}{l}\text { Mengucapkan kata pada /-s/ ' } \\
\text { tas' }\end{array}$ & & & 1 & & & 2 & & \\
\hline 10 & $\begin{array}{l}\text { Mengucapkan kata pada /-s/ } \\
\text { 'bus' }\end{array}$ & & & 1 & & & 2 & & \\
\hline 11 & $\begin{array}{l}\text { Mengucapkan kata pada /-s-/ } \\
\text { 'tikus' }\end{array}$ & & & 1 & & & 2 & & \\
\hline & Jumlah Total & & & 11 & & & & & \\
\hline
\end{tabular}

Keterangan:

Mampu (M) : Apabila klien mengucapkan konsonan tanpa adanya nasal air emission (0 $\mathrm{cm})$, di beri nilai 3

Cukup Mampu (CM) : Apabila klien mengucapkan konsonan dengan adanya nasal air emission (1$2 \mathrm{~cm}$ ), diberi nilai 2

Kurang Mampu (KM) : Apabila klien mengucapkan konsonan dengan adanya nasal air emission (3$4 \mathrm{~cm})$, diberi nilai 1

Tidak Mampu (TM) : Apabila klien mengucapkan konsonan dengan adanya nasal air emission (> $5 \mathrm{~cm})$, diberi nilai 0

Setelah klien menjalani terapi sebanyak 15 kali dan 1 kali evaluasi, terjadi peningkatan beberapa skor menjadi 20 poin sebelumnya mendapat 11 poin dari total skor keseluruhan 31 poin. Berikut adalah perhitungan untuk menentukan perbandingan peningkatan antara tes awal sebelum terapi dan tes akhir sesudah terapi :

Jumlah tes akhir - Jumlah tes awal

$$
20-11=9
$$

Hasil tes awal pasien mendapat nilai 11 poin dan hasil tes akhir pasien mendapat 20 poin. Berikut perhitungan untuk menentukan skala persentase nilai hasil tes awal yaitu :

$$
\frac{\text { nilai hasil tes awal }}{\text { jumlah item keseluruhan }} \times 100 \%
$$




$$
\frac{11 \times 100 \%}{31}=35,5 \%
$$

Berikut perhitungan untuk menilai skala persentase nilai hasil tes akhir yaitu :

$$
\begin{gathered}
\frac{\text { nilai hasil tes akhir }}{\text { jumlah item keseluruhan }} \times 100 \% \\
\frac{20}{31} \times 100 \%=64,5 \%
\end{gathered}
$$

Berikut adalah perhitungan untuk menentukan skala keberhasilan terapi yaitu :

$$
\begin{gathered}
\frac{\text { nilai hasil tes akhir - nilai hasil tes awal }}{\text { nilai maksimal }} \times 100 \% \\
\frac{20-11}{31} \times 100 \%=29,0 \%
\end{gathered}
$$

Berdasarkan hasil tes diatas didapatkan kriteria keberhasilan terapi disesuaikan dengan kiteria keberhasilan dengan cara rumusan secara normatif dengan 4 kategori sebagai berikut:

Tabel 3. Skala Keberhasilan secara kondisi

\begin{tabular}{|c|c|c|c|}
\hline No & Kenaikan Respon & Skala Presentase & Skala Keberhasilan \\
\hline 1. & $29-33$ & $78 \%-100 \%$ & Sangat Berhasil \\
\hline 2. & $24-28$ & $51 \%-75 \%$ & Berhasil \\
\hline 3. & $\mathbf{1 9 - 2 3}$ & $\mathbf{2 7 \% - 4 8 \%}$ & Cukup Berhasil \\
\hline 4. & $11-18$ & $0 \%-24 \%$ & Kurang Berhasil \\
\hline
\end{tabular}

Berdasarkan hasil diatas diketahui bahwa klien mengalami peningkatan respon sebesar $29 \%$ dan masuk pada skala keberhasilan cukup berhasil

\section{KESIMPULAN}

Berdasarkan hasil observasi dan wawancara yang dilakukan terhadap pasien dan keluarganya maka diketahui bahwa klien mengalami gangguan disglosia berupa tidak sempurnanya pembentukan organ wicara pada proses pertumbuhan janin yang diakibatkan kekurangan asupan nutrisi pada saat kehamilan trimester pertama. Setelah melalui perbaikan organ wicara melalui pembedahan labio palate schizis, hasil test artikulasi memperlihatkan bahwa suara klien terdengar sengau atau hipernasal dan terdapat nasal air emission pada konsonan sibilant apicoalveolar/s/. Metode Culde-sac diaplikasikan melalui tahapan mulai dari stimulasi pendengaran klien, lalu setelah memperdengarkan bunyi suara 's' yang seharusnya, klien dilatih untuk mempraktekkan dan merasakan bagaimana bunyi 's' itu seharusnya dikeluarkan dan disuarakan dengan tepat dengan bantuan teknik nose pinching. Metode cul-de-sac digunakan dengan pertimbangan bahwa metode 
ini cukup sederhana dan dapat diterapkan pada klien yang masih berusia anak-anak. Setelah klien diberi treatment dengan metode cul-de-sac sebanyak 15 kali pertemuan, maka dilakukan evaluasi dengan membandingkan hasil pretest sebelum treatment diberikan dan post test setelah pemberian treatment. Hasil perbandingan pretest dan post test menunjukkan adanya peningkatan kemampuan klien dalam mengurangi nasal air emission dalam mengartikulasikan konsonan sibilant apicoalveolar/s/ dari poin 11 pada pretest menjadi 20 pada post test. Dari total item keseluruhan sebanyak 31 poin maka didapat persentase nilai hasil tes akhir adalah $64,5 \%$ dengan persentase skala keberhasilan penerapan metode cul-de-sac sebanyak $29,0 \%$ dan termasuk ke dalam kategori cukup berhasil. Berdasarkan persentase skala keberhasilan tersebut dapat disimpulkan bahwa penerapan metode cul-de-sac cukup berhasil diterapkan pada klien disglosia anak pasca operasi labio palate schizis. Dengan hasil ini, penulis berharap penelitian berikutnya dilakukan dengan pemberian treatment dengan metode yang berbeda untuk mendapatkan teknik yang lebih mampu meningkatkan kemampuan artikulasi pada klien disglosia pasca operasi labio palate schizis.

\section{UCAPAN TERIMA KASIH}

Peneliti mengucapkan terima kasih yang sebesar-besarnya kepada Politeknik Al Islam Bandung yang sudah mendanai penelitian ini melalui program Penelitian Dosen Pemula, dan terimakasih juga kepada Yayasan Penderita Celah Bibir dan Langit-langit Cleft Center serta semua pihak atas dukungan dan partisipasinya dalam penelitian ini.

\section{DAFTAR PUSTAKA}

Arisman. (2009). Gizi dalam Daur Kehidupan. Jakarta: EGC.

ATW. (1995). Disglosia teori dan penangannnya. Jakarta: Yayasan Bina Wicara

Bloot, M. (2009). Ensiklopedia Kehamilan Hari Demi Hari. (Y.A. Putri, Rartri Medya S, Eds., \& Risnawiyati, Trans.) London: Erlangga

Cholid, Zainul. (2013). Celah Palatum. Jurnal Kedokteran Gigi, Vol. 10 No 2.

Eppy Setiyowati. (2017). Pengaruh Kebutuhan Gizi Terhadap Perubahan Berat Badan Ibu Hamil di Desa Petis RT 02 RW 02 Kecamatan Duduk Sampeyan Kabupaten Gresik. Medical Technology and Public Health Journal.

Stuckey, Kevin. (2006). Nasal Emission In P .Ann W.Kummer, Evaluation and treatment using 'low tech' and 'no tech' procedures. The ASHA Leader.

Muhamad et al. (2014). Cleft Lip and Palate; A Comprehensive Review. Centre for Info Bio Technology (CIBTech) pp.338-355.

Sugiyono. (2011). Memahami Penelitian Kualitatif. Bandung: Alfabeta.

Sunanto, Juang, dkk (2006). Penelitian dengan Subjek Tunggal. Bandung: UPI Press

Suripto, S. (2005). In Sardjono, Terapi Wicara (p.20). Jakarta.

Tarigan, H. G. (2008) (n.d) Iin Parlina Sundami. Retrieved Desember 2016, From Kompasiana Beyond Blogging m.kompasiana.com/iinparlinasundami/meningkatkan -kompetensiberbicara-pada -siswa_583fb69273fd0ba91724

Warren et al. (1988). Effects of cleft lip and palate on the nasal airway in children. National Center for Biotechnology Information, National Library of Medicine, 114(9):987-92

Yani, F. T. (2013). Panduan Klinis Kehamilan dan Persalinan. Jogyakarta: D-Medika

Ysunza, Antonio et al., (2004). Surgery for speech in cleft palate patients. International Journal of Pediatric Otorhinolaryngology, 68(12):1499-505 